\title{
Implementasi Nilai-Nilai Hak Asasi Manusia Global ke dalam Sistem Hukum Indonesia yang Berlandaskan Pancasila
}

\author{
Yuli Asmara Triputra \\ Politeknik Negeri Sriwijaya \\ Jln. Srijaya Negara Bukit Besar Palembang \\ yuliasmaratriputra@gmail.com
}

\begin{abstract}
The main issue of this research is about the implementation of global human rights values into the Indonesian legal system based on Pancasila. This research was normative legal research. The results concluded that the implementation of global human rights values into the legal system of a country cannot ignore the values that exist in the community concerned. Indonesia uses Pancasila as its legal ideals, which will then influence and serve as a guiding principle, criticism (norms of evaluation) and motivating factors in the organization of law (the establishment, discovery and application of law) as well as legal behavior. This puts Pancasila as a guiding star (leitstern) for the enactment of human rights law in Indonesia so as to make it in line with the human rights values contained in Pancasila and the 1945 Constitution of the Republic of Indonesia. Pancasila has become the basis of consistency binding of Indonesian legal system, so that the human rights norms contained in the 1945 Constitution of the Republic of Indonesia can serve both regulative and constitutive functions. The regulative function puts the human rights norms in the constitution (UUD) as a benchmark to see whether a law or positive law has been in line with the human rights ideals based on Pancasila. As a constitutive function that determines without the spirit of human rights in the Constitution, laws or positive laws will lose their meaning as a law that brings benefits to the society.
\end{abstract}

Keywords: Pancasila; human rights; human rights norms; implementation

\section{Abstrak}

Indonesia sebagai negara hukum dan bagian dari warga masyarakat dunia, tidak dapat bersikap apatis terhadap persoalan hak asasi manusia (HAM). Permasalahan dalam penelitian ini mengenai implementasi nilai-nilai HAM global ke dalam sistem hukum Indonesia yang berlandaskan Pancasila. Jenis penelitian yang digunakan dalam penelitian ini adalah penelitian hukum normatif. Hasil penelitian menyimpulkan bahwa implementasi nilai-nilai HAM global ke dalam sistem hukum suatu negara tidaklah dapat mengabaikan nilainilai yang hidup dalam masyarakat yang bersangkutan. Demikian halnya Indonesia dengan Pancasila sebagai cita hukumnya, yang akan mempengaruhi dan berfungsi sebagai asas umum yang mempedomani (guiding principle), norma kritik (kaidah evaluasi) dan faktor yang memotivasi dalam penyelenggaraan hukum (pembentukan, penemuan, dan penerapan hukum) dan perilaku hukum. Hal ini menempatkan Pancasila sebagai bintang pemandu (leitstem) bagi pembuatan undang-undang HAM di Indonesia agar selaras dengan nilai-nilai HAM yang terdapat pada Pancasila dan UUD NRI 1945. Pancasila telah menjadi dasar pengikat konsistensi dari sistem hukum Indonesia, sehingga norma HAM yang terkandung dalam UUD NRI 1945 dapat berfungsi regulatif maupun konstitutif. Fungsi regulatif menempatkan norma HAM dalam konstitusi (UUD) sebagai tolok ukur untuk menguji, apakah undang-undang atau hukum positif telah selaras dengan cita-cita HAM yang didasarkan pada Pancasila. Sebagai fungsi konstitutif menentukan tanpa semangat HAM dalam UUD, undang-undang atau hukum positif akan kehilangan makna sebagai hukum yang bermanfaat untuk kemaslahatan masyarakat.

Kata-kata Kunci: Pancasila; hak asasi manusia; norma HAM; implementasi. 


\section{Pendahuluan}

Indonesia adalah negara hukum, ini bermakna bahwa setiap penyelenggaraan bernegara di Republik Indonesia (RI) haruslah dilandaskan pada hukum yang berlaku, tidak terkecuali persoalan Hak Asasi Manusia (HAM). ${ }^{1}$

Membicarakan HAM bukanlah hal baru², sejarah perkembangannya meliputi sejumlah abad, hingga abad ke-13 di Benua Inggris, yang terkenal dengan Piagamnya Magna Charta (1215), Petition of Rights (1689). HAM merupakan nilai universal $^{3}$, sehingga bangsa dan negara Indonesia, sebagai warga masyarakat dunia tidak dapat bersikap apatis. Implementasi nilai-nilai HAM dalam negara hukum Indonesia haruslah dirumuskan dalam peraturan perundang-undangan yang jelas dan tegas serta cara bagaimana menjalankan dan mempertahankannya. Ditinjau secara obyektif, HAM merupakan kewenangan ${ }^{4}$ yang melekat pada manusia sebagai manusia, yang harus diakui dan dihormati oleh pemerintah.

Salah satu wacana yang paling hangat ketika membicarakan penerapan HAM pada skala nasional, yaitu universalisme (universalism) dan relativisme budaya (cultural relativism). Universalisme menyatakan bahwa akan semakin banyak budaya "primitif" yang pada akhirnya berkembang untuk kemudian memiliki sistem hukum dan hak yang sama dengan budaya Barat. Relativisme budaya, di sisi lain, menyatakan sebaliknya, bahwa suatu budaya tradisional tidak dapat diubah. ${ }^{5}$

${ }^{1}$ Seperti diketahui, dalam negara hukum dan demokrasi akan terdapat sistem pembagian kekuasaan dan perlindungan HAM yang diatur dalam konstitusi. Bahkan dalam konstitusi itu, menurut Miriam Budiardjo, ditentukan secara tegas pembatasan kekuasaan pemerintah serta jaminan HAM warga negara karena konstitusi merupakan hukum tertinggi yang harus dipatuhi oleh negara dan pejabat-pejabat pemerintah sesuai dengan dalil “government by laws, not by men”.Miriam Budiardjo, Dasar-dasar Ilmu Politik, Gramedia, Jakarta, 1997, hlm. 52

${ }^{2}$ Ketua MPRS RI, Jendral A.H. Nasution menyatakan : "bakikat HAM sesunggubnya sama tuanya dengan adanya manusia di dunia ini. Tetapi agaknya telah menjadi bukum sejarah, bahwa persoalan HAM timbul pada saat hak asasi tersebut ditindas atau diabaikan oleh suatu kekuasaan”. Mahadi, Pandangan Umum tentang HAM, dalam OK. Saidin, Mencari dan Menjadi Hukum Indonesia, Refleksi Pemikiran Prof. Mahadi, PT. Raja Grafindo Persada, Jakarta, 2016, hlm. 321.

${ }^{3}$ Menurut Gunawan Setiardja, dalam bukunya yang berjudul Hak-Hak. Asasi Manusia Berdasarkan Ideologi Pancasila, Kanisius, Yogyakarta, 1993, hlm. 74. Menyatakan "Barangsiapa beranggapan bahwa HAM itu hanya berlaku dengan syarat-syarat tertentu, hanya dalam lingkungan kebudayaan tertentu, dengan premis-premis metafisika Barat atau berangkat dari teologi Kristen, sesungguhnya tidak berbicara tentang HAM, melainkan tentang hak-hak orang Eropa dan Amerika, hak-hak orang Kristen, atau hak-hak warga negara demokrasi yang berorientasi Barat".

4 Terdapat perbedaan "antara" hak dan "kewenangan". Adapun "hak" adalah kekuasaan (dalam arti sempit) yang dialokasikan oleh hukum kepada seseorang untuk bertindak guna melindungi kepentingannya terhadap orang lain yang menjadi pemegang kewanjiban. Sedangkan "kewenangan" adalah berupa hak [yang tidak mempunyai pasangan yang berupa kewajiban (pada orang lain)] yang diberikan kepada seseorang untuk, melalui jalur hukum, mewujudkan kemauannya guna mengubah hak-hak, kewajiban-kewajiban, pertanggungjawaban atau lain-lain hubungan hukum, baik dari dirinya sendiri maupun orang lain. (vide Satjipto Rahardjo, Ilmu Hukum, PT.Citra AditBakti, Bandung, hlm. 53-58.

${ }^{5}$ Rhona K. M. Smith, dkk., dalam Knut D. Asplund, Suparman Marzuki, Eko Riyadi (editor), Hukum Hak. Asasi Manusia, Pusat Studi Hak Asasi Manusia Universitas Islam Indonesia, Yogyakarta, Cet. Kedua, 2010, hlm. 18. 
Rasa tanggung jawab terhadap kemanusiaan, tidaklah serta-merta membuat para pembuat kebijakan dalam mengimplementasikan nilai-nilai HAM global ${ }^{6}$ tanpa mempertimbangkan faktor-faktor seperti pandangan agama, keamanan dan ketentraman dalam masyarakat yang sedikit banyaknya berpengaruh kepada penghormatan HAM. ${ }^{7}$

Pembuatan dan penegakan hukum merupakan instrumentasi putusan dan keinginan politik yang dalam pandangan David Trubeck disebutnya "purposive human action"8. Dengan kata lain, pembuatan UU tidak pernah bersifat otonom dan steril, melainkan sarat dengan kepentingan-kepentingan kelompok atau kekuatankekuatan potensial dalam suatu negara yang menginginkan kepentingannya dilegalisasi atau diproteksi dalam UU karena UU, menurut Schuyt sebagaimana dikutip Duverger, merupakan "een neerlag van politieke machtsverhoudingen" (suatu endapan pertukaran antarkekuatan politik dalam masyarakat). ${ }^{9}$

\section{Rumusan Masalah}

Permasalahan dalam penelitian ini adalah bagaimana implementasi nilainilai HAM global ke dalam sistem hukum Indonesia yang berlandaskan Pancasila?

\section{Tujuan Penelitian}

Penelitian ini difokuskan pada tujuan utama, yakni hendak mengetahui dan melakukan analisis terhadap implementasi nilai-nilai HAM global ke dalam sistem hukum Indonesia yang berlandaskan Pancasila.

\section{Metode Penelitian}

Penelitian ini merupakan penelitian hukum normatif, yaitu penelitian terhadap data sekunder yang diperoleh melalui studi Pustaka. Data sekunder dalam penelitian ini berupa bahan hukum primer yakni perundang-undangan yang berkaitan dengan

${ }^{6}$ HAM Global adalah HAM yang bersifat universal yang dimiliki oleh individu terlepas dari nilai-nilai atau budaya yang dimiliki oleh suatu masyarakat ataupun yang ada pada suatu negara, sebagaimana yang dikembangkan para penganut teori universalitas.

${ }^{7}$ Mahadi, Op. Cit., hlm. 332.

8 "...modern law has three principal characteristic; it is primarily a system of rules; it is a form of purposive human action; and it is simultaneously part of, yet autonomous from, the nation state", David M. Trubeck, "Toward a Social Theory of Law; An Essay in the Study of Law and Development”, dalam The Yale Law Journal, 1972, Vol. 82, hlm.4.

9 Satjipto Rahardjo, Sosiologi Hukum, Perkembangan Metode dan Pilihan Masalah, Muhamadiyah University Press, Surakarta, 2004, hlm. 127. 
HAM serta bahan hukum sekunder berupa literatur dan pendapat para pakar yang berkaitan dengan permasalahan.Data yang terkumpul dianalisis secara kualititatif, yaitu analisis yang didasarkan pada nilai, kualitas dan keadaan data yang diperoleh. Dengan kata lain, pencarian kebenaran dalam penelitian ini didasarkan dan diukur dengan kualitas, nilai dan keadaan data yang bersangkutan.

\section{Hasil Penelitian dan Pembahasan}

\section{Konsep Dasar HAM}

HAM adalah hak-hak yang dimiliki manusia semata-mata karena ia manusia, bukan karena diberi oleh masyarakat, atau berdasarkan hukum positif, melainkan semata-mata berdasarkan martabatnya sebagai manusia. ${ }^{10}$ Dalam arti ini, meskipun setiap orang terlahir dengan warna kulit, jenis kelamin, bahasa, budaya dan kewarganegaraan yang berbeda-beda, tetap mempunyai hak-hak tersebut. Inilah sifat universal dari HAM. Hak-hak tersebut tidak dapat dicabut (inalienable). Artinya, seburuk apapun perlakuan yang telah dialami oleh seseorang atau betapapun bengisnya perlakuan seseorang, tidak akan berhenti menjadi manusia dan tetap memiliki hak-hak tersebut. ${ }^{11}$

Gagasan di atas, bersumber dari teori hak kodrati (natural rights theory) yang bermula dari teori hukum kodrat (natural law theory), Santo Thomas Aquinas ${ }^{12}$, yang dikembangkan lebih lanjut oleh Hugo de Groot (Grotius) dengan memutus asal-usulnya yang teistik dan menjadikannya produk pemikiran sekuler yang rasional. Pasca renaissance, John Locke, mengajukan pemikiran mengenai hak-hak kodrati, yang melandasi munculnya revolusi hak dalam revolusi di Inggris, Amerika Serikat (AS) dan Perancis pada abad ke-17 dan ke-18.

Locke, berpendapat bahwa semua individu dikarunia oleh alam hak yang melekat atas hidup, kebebasan dan kepemilikan, yang merupakan milik mereka

${ }^{10}$ Jack Donnely, Universal Human Rights in Theory and Practice, Cornell University Press, Ithaca and London, 2003, hlm. 7-21.

${ }^{11}$ Rhona K. Smith, Op. Cit, , hlm. 11.

${ }^{12}$ Dalam teori hukum kodratnya, Thomas Aquinas berpijak pada pandangan Thomistik yang mempostulasi hukum kodrati sebagai bagian dari hukum Tuhan yang sempurna dan dapat diketahui melalui penggunaan nalar manusia. 
sendiri dan tidak dapat dicabut atau dipreteli oleh negara. ${ }^{13}$ Melalui "kontrak sosial" (social contract), perlindungan hak ini diserahkan kepada negara. Ketika negara mengabaikannya, membebaskan rakyat menurunkan sang penguasa dan menggantinya dengan suatu pemerintah yang bersedia menghormati hak-hak tersebut. Melalui teori ini, maka eksistensi hak-hak individu yang pro-positif mendapat pengakuan kuat.

Pandangan Locke ini banyak mendapat tentangan ${ }^{14}$, namun pamornya tampil kembali pada masa akhir Perang Dunia II dan mengilhami kemunculan gagasan HAM di panggung internasional ${ }^{15}$. Pengalaman Holocaust Nazi, membuat dunia berpaling kembali kepada gagasan Locke tentang hak-hak kodrati. Dengan mendirikan PBB pada 1945, masyarakat internasional tidak ingin mengulang terjadinya holocaust di masa depan, dan karena itu "menegaskan kembali kepercayaan terhadap HAM, terhadap martabat dan kemuliaan manusia, kesetaraan hak laki-laki dan perempuan, dan kesetaraan negara besar dan kecil. ${ }^{16}$

Internasionalisasi gagasan HAM yang disepakati sebagai "tolok ukur pencapaian bersama bagi semua rakyat dan semua bangsa" (a commond standard of achievement for all peoples and all nations) ditandai dengan diterimanya suatu rezim hukum HAM internasional yang disiapkan oleh PBB yakni International Bill of Human Rights, yang terdiri atas empat dokumen, yaitu: 1). Universal Declaration of Human Rights 194817; 2). International Covenant on Economic, Social and Cultural Rights

${ }^{13}$ John Locke, The Second Treatise of Civil Government and a Latter Concerning Toleration, disunting oleh J.W. Gough, Blackwell, Oxford, 1964, sebagaimana dikutip Rhona K. Smith, dkk, dalam Knut D. Asplund, Suparman Marzuki, Eko Riyadi (editor), Loc.Cit.

14 Penentang teori hak kodrati yang paling terkenal adalah Jeremy Bentham. Kritiknya yang mendasar terhadap teori tersebut, bahwa teori hak-hak kodrati tidak bisa dikonfirmasi dan diverifikasi kebenarannya. Bentham mengatakan "hak sebagai kata benda (berlawanan dengan kata sifat), adalah anak kandung hukum; dari hukum lahir pula hak-hak riil; namun dari hukum imajiner; hukum kodrati -yang dikhayal dan direka para penyair, ahli-ahli pidato dan saudagar dalam rupa racun moral dan intelektual- lahirlah hak-hak rekaan... Hak-hak kodrati adalah omong kosong yang dungu; hak yang kodrati dan tidak bisa dicabut adalah omong kosong yang retorik atau puncak dari omong kosong yang berbahaya" (LIhat H.L.A. Hart, Essays on Bentham, Oxford University Press, London, 1982, hal. 82). Serangan dan penolakan kalangan utilitarian itu kemudian diperkuat oleh mazhab positivisme yang dikembangkan belakangan dengan sistematis oleh John Austin. Kaum positifis berpendapat bahwa eksistensi dan isi hak hanya dapat diturunkan dari hukum negara. satu-satunya hukum yang sahih adalah perintah dari yang berdaulat. Ia tidak datang dari "alam" atau "moral".

15 David Weissbordt, Hak. Asasi Manusia, Tinjanan dari Perspektif Sejarah, dalam Peter Davies, Hak Asasi Manusia; Sebuah Bunga Rampai, Yayasan Obor Indonesia, Jakarta, 1994, hlm. 1-30.

16 Preambule Piagam PBB.

${ }^{17}$ Declaration of Human Right 1948 diinspirasi oleh gagasan Franklin D Roosevelt, pada permulaan abad ke-20 yang memformulasikan empat macam hak-hak asasi yang dikenal dengan "The Four Freedoms" yaitu : Freedom of Speech (kebebasan berbicara dan mengemukakan pendapat), Freedom of Religion (kebebasan beragama), Freedom from 
(ICESCR) 1966; 3). International Covenant on Civil and Political Rights (ICCPR) 1966;

4). Optional Protocol to the International Covenant on Civil and Political Rights 1966.

\section{Prinsip-prinsip HAM}

Beberapa prinsip telah menjiwai HAM internasional18, antara lain :

Prinsip kesetaraan (equality,) merupakan suatu ide yang meletakkan semua orang terlahir bebas dan memiliki kesetaraan dalam HAM, dimana pada situasi yang sama harus diperlakukan sama dan pada situasi yang berbeda diperlakukan berbeda pula. ${ }^{19}$

Dalam prinsip kesetaraan, dikenal tindakan afirmatif (diskriminasi positif). Hal ini muncul ketika seseorang yang berasal dari posisi yang berbeda tetapi diperlakukan sama. Jika perlakuan sama ini terus diberlakukan maka perbedaan ini akan menjadi terus menerus walaupun standar HAM telah ditingkatkan. Untuk itulah penting untuk mengambil langkah selanjutnya guna mencapai kesetaraan dengan catatan tindakan afirmatif ini hanya dapat digunakan dalam suatu ukuran tertentu hingga kesetaraan itu dicapai. Jika kesetaraan telah tercapai maka tindakan afirmatif tidak dibenarkan lagi.

Pelarangan diskriminasi (non discrimination) ${ }^{20}$. Jika semua orang dianggap setara, maka seharusnya tidak ada perlakuan diskriminatif disamping tindakan afirmatif dalam rangka mencapai kesetaraan. Pada dasarnya diskriminasi merupakan kesenjangan perbedaan perlakuan dari perlakuan yang seharusnya sama atau setara. ${ }^{21}$

Prinsip Ketergantungan (interdefendance). Prinsip ini menegaskan bahwa pemenuhan hak seringkali bergantung kepada pemenuhan hak lainnya, baik secara keseluruhan maupun sebagian.

Selanjutnya prinsip dipertukarkan (inalienable). Pemahaman prinsip atas hak yang tidak bisa dipindahkan, tidak bisa dirampas atau dipertukarkan dengan hal

Fear (kebebasan dari rasa ketakutan), dan Freedom from Want (kebebasan dari kemelaratan). (Kaelan, Op. Cit., hlm. 250).

${ }^{18} \mathrm{http}: / /$ pamflet.or.id/blog/hamitukita-6-prinsip-dasar-ham, diakses tanggal 17 Maret 2017.

${ }^{19}$ Jauhariah, Dinamika Hukum \& HAM, Penerbit Cintya Press, Jakarta, 2016, hlm. 79-80.

20Diskriminasi ini terbagi menjadi diskriminasi langsung dan diskriminasi tidak langsung. Diskriminasi langsung ialah ketika seseorang baik secara langsung maupun tidak langsung diperlakukan dengan berbeda daripada yang lainnya, sedangkan diskriminasi tidak langsung muncul ketika dampak dari hukum atau dalam praktik hukum merupakan diskriminasi walaupun hal itu tidak ditujukan untuk tujuan diskriminasi.

${ }^{21}$ Juahariah, Loc. Cit. 
tertentu, agar hak-hak tersebut bisa diperkecualikan. Hak-hak individu tidak dapat direnggut, dilepaskan dan dipindahkan.

Prinsip ketergantungan (indivisibility). Prinsip ini sebenarnya merupakan pengembangan dari prinsip saling terkait. HAM baik hak sipil, politik, sosial, budaya, ekonomi semuanya bersifat inheren, yaitu menyatu dalam harkat martabat manusia. Pengabaian pada satu hak akan menyebabkan pengabaian terhadap hakhak lainnya.

Prinsip selanjutnya terkait dengan universalisme HAM. Prinsip universal (universality) merupakan prinsip yang tertinggi dimana HAM itu berlaku secara keseluruhan dimana pun seseorang berada di dunia ini.

Prinsip yang terakhir yakni terkait dengan martabat manusia (human dignity). Hak asasi merupakan hak yang melekat, dan dimiliki setiap manusia di dunia. Prinsip ini menegaskan perlunya setiap orang untuk menghormati hak orang lain, hidup damai dalam keberagaman yang bisa menghargai satu dengan yang lainnya, serta membangun toleransi sesama manusia.

\section{Derogable Rights $\mathcal{E}$ Non-Derogable Rights ${ }^{22}$}

Derogable Rights adalah hak-hak yang boleh dikurangi atau dibatasi pemenuhannya oleh negara-negara pihak. Termasuk ke dalam jenis ini adalah: a. hak atas kebebasan menyatakan pendapat atau berekspresi, termasuk kebebasan mencari, menerima dan memberikan informasi dan segala macam gagasan tanpa memperhatikan batas (baik melalui lisan maupun tulisan); ${ }^{23}$ b. hak atas kebebasan berkumpul secara damai, ${ }^{24} \mathrm{c}$. hak atas kebebasan berserikat termasuk membentuk dan menjadi anggota serikat buruh. ${ }^{25}$

Berbeda dengan derogable rights, terhadap hak-hak dalam kategori nonderogable rights, hanya dapat disimpangi jika sebanding dengan ancaman yang dihadapi dan tidak bersifat diskriminatif, yaitu demi (i) menjaga keamanan

\footnotetext{
${ }^{22}$ Pengklasifikasian Derogable Rights dan Non-Derogable Rights adalah sesuai dengan ICCPR. ICCPR ini telah diratifikasi Indonesia melalui UU No. 12 Tahun 2005 tentang Pengesahan International Covenant on Civil and Political Rights (Kovenan Internasional tentang Hak-Hak Sipil dan Politik).

23 Pasal 19 ICCPR.

24 Pasal 21 ICCPR.

${ }^{25}$ Pasal 22 ICCPR.
} 
nasional atau ketertiban umum atau kesehatan atau moralitas umum dan (ii) menghormati hak atau kebebasan orang lain.

Di Indonesia non-derogable rights dirumuskan dalam UUD NRI 1945 Pasal 28 I ayat (1) yang berbunyi :

Hak untuk hidup, hak untuk tidak disiksa, hak kemerdekaan pikiran dan hati nurani, hak beragama, hak untuk tidak diperbudak, hak untuk diakui sebagai pribadi di hadapan hukum, dan hak untuk tidak dituntut atas dasar hukum yang berlaku surut adalah HAM yang tidak dapat dikurangi dalam keadaan apapun. ${ }^{26}$

Di dalam ICCPR, hak-hak yang sama sekali tidak boleh dikurangi karena sangat mendasar27, yaitu: hak atas hidup (Pasal 6); hak bebas dari penyiksaan (Pasal 7); hak bebas dari perbudakan (Pasal 8); hak bebas dari penahanan karena gagal memenuhi perjanjian [utang](Pasal 11); hak bebas dari pemidanaan yang berlaku surut (Pasal 15); hak sebagai subyek hukum (Pasal 16); dan hak atas kebebasan berpikir, keyakinan dan agama (Pasal 18). ${ }^{28}$

\section{Pancasila sebagai Nilai Fundamental Bangsa}

Masa kolonial mengharuskan pemberlakuan peraturan-peraturan kolonial melalui konkordansi maupun unifikasi hukum, namun sejak kemerdekaan, Indonesia harus membangun sistem hukumnya sendiri. ${ }^{29}$ Para founding fathers telah merumuskan Pancasila sebagai nilai-nilai fundamental Bangsa Indonesia30,

${ }^{26}$ Sebelum dirumuskan dalam UUD NRI 1945, ketentuan sudah ditegaskan pula dalam Tap MPR No. XVII/ MPR/ 1998 tentang HAM dan juga di dalam UU No. 39 Tahun 1999 tentang HAM pada Pasal 4, dengan narasi yang sama yang tercantum dalam UUD NRI 1945.

27 Negara-negara pihak yang melakukan pelanggaran terhadap hak-hak dalam jenis ini, seringkali akan mendapat kecaman sebagai negara yang telah melakukan pelanggaran serius HAM (gross violation of human rights), lihat Miftakhul Huda, "Kamus Hukum Non-Derogable Rights”, Majalah Konstitusi No. 43, Agustus 2010, hlm. 101.

${ }^{28}$ Sesuai dengan norma ICCPR, The European Convention of Human Rights dan American Convention on Human Rights membagi empat macam hak non-derogable yakni : hak untuk hidup, hak untuk bebas dari penyiksaan dan perlakuan yang tidak manusiawi atau merendahkan atau hukuman lainnya, hak untuk bebas dari perbudakan atau penghambaan, dan hak untuk bebas dari penerapan retroaktif hukum pidana. Hak-hak ini dikenal sebagai norma hukum internasional yang harus ditaati (jus cogens norms).

${ }^{29}$ Darji Darmodiharjodan Sidharta menyatakan bahwa : Proklamasi 17 Agustus 1945 oleh SoekarnoHatta, dan penetapan UUD 1945 satu hari sesudahnya, menjadi titik awal dimulainya tertib hukum Indonesia". (LIhat Darji Darmodiharjodan Sidharta, Penjabaran Nilai-Nilai Pancasila dalam Sistem Hukum Indonesia, PT. Raja Grafindo Persada, Jakarta, 1996, hlm. 163.

30Pancasila ikut berproses dalam sejarah bangsa Indonesia. Pancasila sebagai dasar Negara sering diinterpretasikan sesuai kepentingan kekuasaan yang silih berganti. Pada akhirnya kesepakatan bangsa terwujud melalui Ketetapan MPR No. XVIII/ MPR/ 1998 tentang Pencabutan Ketetapan MPR RI No. II/ MPR/ 1978 tentang Pedoman Penghayatan dan Pengamalan Pancasila (Eka Prasetya Pancakarsa) dan Penetapan tentang Penegasan Pancasila sebagai dasar Negara. Pasal 1 nya menyatakan bahwa Pancasila sebagaimana dimaksud dalam Pembukaan UUD 1945 adalah dasar NKRI yang harus dilaksanakan secara konsisten dalam kehidupan bernegara. Catatan risalah/ penjelasan yang merupakan bagian tak terpisahkan dari ketetapan tersebut menyatakan bahwa 
merupakan dasar pengikat konsistensi dari sistem hukum Indonesia ${ }^{31}$. Pancasila, sebagai sumber hukum yang paling dasar ${ }^{32}$, merupakan sumber tertib hukum di Indonesia.

Pancasila sebagai nilai fundamental, berkedudukan juga sebagai cita hukum (rechtsidee) bangsa Indonesia. Arief Sidharta menyatakan bahwa :

“Tata hukum yang beroperasi dalam suatu masyarakat pada dasarnya merupakan pengejawantahan cita hukum yang dianut dalam masyarakat ke dalam berbagai aturan hukum positif, lembaga hukum, dan proses perilaku birokrasi pemerintahan dan warga masyarakat".

Cita hukum ini, belum cukup konkrit untuk dapat digunakan langsung sebagai sumber hukum formal, karena berada dalam tataran nilai. Untuk itu, perlu konkritisasi ke dalam norma-norma positif. ${ }^{33}$ Konkrititasi nilai-nilai Pancasila dirumuskan dalam UUD NRI 1945 yang dituangkan dalam Pembukaan dan peraturan-peraturan lain yang lebih rendah ${ }^{34}$. Sehubungan dengan ini, Francis F. Jocobs menyatakan :

"The nation that there is a basic or fundamental law (confusingly sometimes known as a higher law) can be traced back for many centuries. The essential idea is that the ordinary laws, even those made by the 'sovereign', are subject to fundamental law, and can therefore be held invalid if they transgress it". ${ }^{35}$

Semua peraturan dalam sistem hukum Indonesia haruslah tidak bertentangan dengan Pancasila, dan UUD NRI 1945. Pertentangannya dapat

dasar Negara yang dimaksud dalam ketetapan ini di dalamnya mengandung makna ideologi nasional sebagai citacita dan tujuan Negara. Harapannya tentu saja agar tidak terjadi lagi kesalahan dalam memperlakukan Pancasila. Pancasila hendaknya diperlakukan dengan benar dan wajar dalam konteks kehidupan bernegara Indonesia.

31 Soenarjati Hartono menyatakan "bahwa (sekalipun) sistem hukum Indonesia sudah ada, tetapi belum seutuhnya mengacu kepada Pancasila dan UUD 1945, dan belum berfungsi dan menopang negara hukum yang dicita-citakan. (oleh sebab itu) sistem hukum nasional harus senantiasa diupayakan agar selalu konsisten dengan nilai-nilai Pancasila dan asas serta norma hukum yang tertuang dalam UUD 1945, guna menjamin kepastian hukum, pengayoman dan keadilan". Sebagaimana dikutip Elly Erawati, Benang Merah Pemikiran Soenarjati Hartono tentang Sistem dan Pembangunan Hukum Nasional, serta Pendidikan Tinggi Hukum. dalam Elly Erawati, Bayu Seto Hardjowahono, dan Ida Susanti, BeberapaPemikiran Tentang Pembangunan Sistem Hukum Nasional Indonesia, PT. Citra Aditya Bakti, Bandung, 2011, hlm. 62.

32 Penegasan Pancasila sebagai sumber hukum dinyatakan dalam UU No.12 Tahun 2011. Pasal 2 dan Pasal 3 ayat (1) menyatakan bahwa Pancasila merupakan sumber segala sumber hukum negara dan UUD NRI 1945 merupakan hukum dasar dalam peraturan perundang-undangan RI.

33 Shidarta, Hukum Penalaran dan Penalaran Hukum, Buku 1 Akar Filosofis, Genta Publishing, Yogyakarta, 2013, hlm. 403.

${ }^{34}$ Pasal 7 UU No. 12 Tahun 2011, menegaskan bahwa tata urutan perundang-undangan RI adalah: 1) UUD NRI 1945, 2) Ketetapan MPR, 3) Undang-Undang/ Peraturan Pemerintah Pengganti Undang-Undang, 4) Peraturan Pemerintah, 5) Peraturan Presiden, 6) Peraturan Daerah Provinsi, 7) Peraturan Daerah Kabupaten/ Kota.

${ }^{35}$ Francis G. Jacobs, The Sovereignty of Law; The European Way, Cambridge Press, Cambridge, hlm. 5. 
dianggap sebagai peraturan yang tidak sah. ${ }^{36}$ Jelaslah bahwa pada dasarnya pemberlakuan instrument-instrumen HAM di Indonesia haruslah merupakan perwujudan dan pelaksanaan dari nilai-nilai Pancasila.

Mengaitkan HAM sebagai konsepsi universal dengan ideologi bangsa sangatlah relevan, karena sekalipun HAM merupakan sesuatu yang melekat pada manusia secara kodrati, namun operasionalisasinya harus disesuaikan dengan aspek sosial budaya setiap bangsa. Pembatasan (limitation) ini secara implisit juga diakui di dalam dokumen-dokumen internasional (the International Bill of Human Rights), asal didasarkan atas perundang-undangan yang berlaku (the limitations must be determined by law). Alasan yang dapat dikemukakan adalah "for the purpose of securing due recognition of the rights of others and meeting the just requirements of morality, public order and the general welfare in a democratic society". ${ }^{37}$

\section{Implementasi Nilai-nilai HAM Global ke dalam Sistem Hukum Indonesia yang Berlandaskan Pancasila}

\section{Kedudukan Pancasila dalam Sistem Hukum Indonesia}

Tatanan hukum yang beroperasi dalam suatu masyarakat pada dasarnya merupakan pengejawantahan cita hukum ${ }^{38}$ yang dianut masyarakat bersangkutan ke dalam perangkat aturan hukum positif, lembaga hukum dan proses (perilaku birokrasi pemerintahan dan warga masyarakat). ${ }^{39}$ Menurut Sidharta ${ }^{40}$, cita hukum berintikan pada: keadilan, kehasil-gunaan (doelmatigheid) dan kepastian hukum yang terbentuk dalam pikiran dan sanubari manusia sebagai produk berpadunya pandangan hidup, keyakinan keagamaan dan kenyataan kemasyarakatan yang diproyeksikan pada proses pengkaidahan perilaku warga masyarakat yang mewujudkan tiga unsur tersebut.

36 Selanjutnya, proses untuk menyatakan ketidaksahan dari peraturan tersebut harus dilakukan melalui judicial review sebagaimana diatur dalam Pasal 20 dan 29 UU No. 48 Tahun 2009 tentang Kekuasaan Kehakiman (LN. RI Tahun 2009 No. 157).

${ }^{37}$ Muladi dalam Kata Pengantar buku Gunawan Setiardja, Op. Cit., hlm. 12.

38 Cita hukum (rechtsidee) mengandung arti bahwa pada hakikatnya hukum sebagai aturan tingkah laku masyarakat berakar pada gagasan, rasa, karsa, cipta dan fikiran dari masyarakat itu sendiri (Perumusan hasil seminar “Temu Kenal Cita Hukum dan Penerapan Asas-asas Hukum Nasional”) dalam Bernard Arief Sidharta, Op. Cit., hlm. 181.

${ }^{39}$ Ibid., hlm. 180.

${ }^{40}$ Ibid., hlm. 181. 
Cita hukum akan mempengaruhi dan berfungsi sebagai asas umum pemandu (guiding principle), norma kritik (kaidah evaluasi) dan faktor motivasi dalam penyelenggaraan hukum (pembentukan, penemuan, dan penerapan hukum) dan perilaku hukum.Cita hukum Pancasila ditempatkan sebagai bintang pemandu (leitstern) bagi pembuatan UU HAM di Indonesia agar selaras dengan nilai-nilai HAM Pancasila dan UUD 1945.

Hukum positif suatu negara, tidak dapat dilepaskan dengan sistem hukum yang berlaku di negara tersebut ${ }^{41}$. Pancasila sebagai dasar negara ${ }^{42}$, ditambah Pembukaan UUD 1945, terutama alinea pertama yang menyatakan "kemerdekaan ialah hak segala bangsa serta penjajahan harus dihapuskan", serta alinea kedua "kemerdekaan negara menghantarkan rakyat merdeka, bersatu, adil, dan makmur", mengindikasikan Indonesia adalah negara demokrasi, menjunjung tinggi supremasi hukum, serta menghormati/ menjunjung tinggi HAM. Pembukaan UUD 1945 merupakan arah dan politik hukum dalam tataran makro, kemudian diformalkan dalam bentuk peraturan perundang-undangan oleh lembaga politik/ DPR dan dioperasionalkan/ dilaksanakan oleh pejabat/ aparat negara dalam bentuk peraturan pemerintah dan peraturan lainnya sebagai pegangan para birokrat.

Undang-undang selalu mengandung norma-norma hukum yang diidealkan (ideal norms) oleh suatu masyarakat ke arah mana cita-cita luhur kehidupan bermasyarakat dan bernegara hendak diarahkan. Cita-cita filosofis yang terkandung dalam UU hendaklah mencerminkan cita-cita filosofis masyarakat bangsa yang bersangkutan. ${ }^{43}$ Artinya, jangan sampai cita-cita filosofis yang terkandung di dalam UU tersebut justru mencerminkan falsafah kehidupan bangsa lain yang tidak cocok dengan cita-cita filosofis bangsa sendiri, demikian pula

${ }^{41}$ Masyhur Effendi \& Taufani S. Evandri, HAM Dalam Dinamikal Dimensi Hukum, Politik, Ekonomi, dan Sosial, Ghalia Indonesia, Jakarta, 2014, hlm. 155.

${ }^{42}$ Nilai-nilai Pancasila termasuk nilai etik (moral) dan termasuk dalam tingkatan nilai dasar (bersifat fundamental dan tetap), yang mendasari nilai berikutnya, yaitu nilai instrumental. Umumnya nilai instrumental berbentuk norma sosial dan norma hukum yang selanjutnya terkristalisasi dalam peraturan dan mekanisme lembaga-lembaga Negara. Nilai dasar itu mendasari semua aktivitas kehidupan bermasyarakat, berbangsa dan bernegara. Winarno, Paradigma Baru Pendidikan Kewarganegaraan, PT. Bina Aksara, Jakarta, cetakan Kedua, 2008, hlm. 5 .

${ }^{43}$ Jimly Asshiddiqie, Perihal Undang-Undang, PT. Raja Grafindo Persada, Jakarta, 2010, hlm. 116. 
halnya UU RI tentang HAM. Dalam konteks bernegara, Pancasila sebagai falsafah harus tercermin dalam pertimbangan filosofis yang terkandung dalam setiap UU.

Hal ini mutlak perlu, sebab akan berkaitan dengan falsafah, doktrin, dan wawasan bangsa Indonesia, baik secara individual maupun kolektif kehidupan masyarakat yang berasaskan kekeluargaan. Dimana manusia disini dipandang sebagai warga negara. Jadi konsep HAM di Indonesia bukan saja terhadap hak-hak mendasar manusia, tetapi ada kewajiban dasar manusia sebagai warga negara untuk mematuhi peraturan perundang-undangan, hukum tak tertulis, menghormati HAM orang lain, moral, etika, patuh pada hukum internasional mengenai HAM yang telah diterima bangsa Indonesia, juga wajib membela terhadap negara. Sedangkan kewajiban bagi pemerintah untuk menghormati, melindungi, menegakkan, dan memajukan HAM yang telah diatur berdasarkan peraturan perundang-undangan dan hukum internasional ${ }^{44}$.

\section{Nilai-nilai HAM Global}

Globalisasi di bidang politik tidak terlepas dari pergerakan tentang HAM, transparansi, dan demokratisasi. Instrumen HAM semakin berkembang dalam berbagai konvensi dan kovenannya. Perlindungan HAM dijadikan salah satu standar untuk berhubungan dengan negara Barat. Dominasi ekonomi dan ketergantungan negara-negara dunia ketiga (non-komunis) pada bantuan ekonomi Barat, menimbulkan dominasi dan standar Barat dalam penilaian pelaksanaan HAM dunia terutama negara dunia ketiga. ${ }^{45}$

Negara dapat memasukkan norma-norma HAM internasional ke dalam hukum domestiknya sesuai dengan sistem dan mekanisme hukum masing-masing. Standar HAM yang tercermin dalam hukum kebiasaan internasional juga dapat dimasukkan ke dalam hukum nasional (sekurang-kurangnya dengan

${ }^{44}$ Hukum internasional disini dimaksudkan adalah hukum yang bersumber pada : a)international convention, whether general or particular, extablishing rules expressly recognized by the contesting states (perjanjian internasional, baik bersifat umum maupun khusus berisi ketentuan-ketentuan hukum yang diakui secara tegas oleh pihak yang bersengketa), b) International customs, as evidence of general practice accepted as law (kebiasaan-kebiasaan internasional, sebagai bukti dari suatu kebiasaan umum diterima sebagai hukum), c) The general principles of law recognized by civilized nations (prinsip-prinsip hukum umum diakui oleh bangsa-bangsa beradab), d) Subject to the provisions of Article 59, judicial decisions and the teachings of the most hightly qualified publicist of the various nations, as subsidaiary means for the determination of rules of law (keputusan pengadilan dan ajaran-ajaran para sarjana yang paling terkemuka dari berbagai negara sebagai sumber tambahan dalam menetapkan kaidah-kaidah hukum). [Statuta Mahkamah Internasional, Pasal 38 ayat (1)].

${ }^{45}$ Muladi (editor), Op. Cit., hlm.10-11. 
menghilangkan perundang-undangan yang bertentangan atau melalui praktek/ kebijakan pemerintah) sebagai bagian dari "hukum negara" ${ }^{46}$

Globalisasi HAM tidaklah serta-merta membuat pembuat kebijakan menerima konsep-konsep HAM yang berlandaskan falsafah Barat secara universal, namun hendaknya diselaraskan (harmonisasi ${ }^{47}$ ) dengan falsafah serta kebudayaan bangsa Indonesia dengan mengundangkan seperangkat norma hukum HAM ke dalam sistem hukum Indonesia.

Pada tataran teoritis dapat diterima oleh semua negara konsep-konsep HAM yang berlandaskan falsafah Barat, namun dalam implementasi selalu terdapat perbedaan antara negara yang satu dengan lainnya disebabkan sudut pandang yang berbeda ${ }^{48}$. Inilah salah satu faktor implementasi nilai-nilai universal HAM tidak seragam. ${ }^{49}$

Menurut Adil Ul-Yasin \& Archana Upadhyay sebagaimana dikutip Masyhur Effendi dan Taufani S. Evandri50, dengan berpijak dari definisi HAM PBB dan penulis lainnya dapatlah disimpulkan bahwa terdapat karakteristik HAM secara global sebagai berikut :

- It is rights of an individual or a group of individual;

- These a rights are inalienable and human beings are entitled to them by birth;

- It is universal and legal concept;

- These rights are meant to upload dignity and equality and to set fourth liberty and fraternity to all without any kind of discrimination;

${ }^{46}$ Knut D. Asplund, Suparman Marzuki, Eko Riyadi (editor), Op. Cit., hlm. 67.

47 Badan Pembinaan Hukum Nasional Departemen Kehakiman memberikan pengertian harmonisasi hukum, sebagai kegiatan ilmiah untuk menuju proses pengharmonisan hukum tertulis yang mengacu baik pada nilai-nilai filosofis, sosiologis, ekonomis maupun yuridis. Pengkajian terhadap rancangan peraturan perundangundangan, dalam berbagai aspek apakah telah mencerminkan keselarasan dan kesesuaian dengan peraturan perundang-undangan yang lain, hukum tidak tertulis yang hidup dalam masyarakat, konvensi-konvensi dan perjanjian-perjanjian internasional baik bilateral maupun multilateral yang telah diratifikasi Indonesia.Kusnu Goesniadhie, Harmonisasi Hukum, Dalam Perspektif Perundang-undangan (Lex Specialis suatu Masalah), JP BOOKS, Surabaya, 2006, hlm. 71.

${ }^{48}$ Edison Zvobgo, dalam bukunya A Third World View (on buman Rights), yang diterbitkan tahun1979 menulis "Saya yakin bahwa apabila diskusi mengenai Deklarasi Universal HAM dalam Majelis Umum PBB, maka perumusannya yang final akan berubah sekali dibandingkan dengan yang diproklamasikan pada tabun 1948 dabulu. Untuk kami orang Afrika dan Asia, citra manusia yang mendasari Deklarasi HAM itu sama sekali tidak dapat dimengerti. Menurut citranya, manusia adalah seorang individu terpisabkan dari masyarakat dan dianggap sebagai pembawa identitas insane yang lengkap. Manusia semacam itu dalam pandangan bangsa Afrika dan Asia tidak ada. Untuk orang-orang Afrika dan Asia, orang semacam itu, yaitu orang, yang sendirian menentukan jalannya kea rah kebahagiannya sendiri, lepas dari orang-orang lain, ganjil. Singkatnya, untuk orang-orang Afrika dan Asia, makbluk insane itu bukan manusia seperti yang digambarkan oleb Jobn Locke, disinilab letak perbedaan bakiki antara pandangan dunia ketiga dan dunia yang pertama”. (Lihat, Gunawan Setiardja, Op. Cit. hlm. 100).

${ }^{49}$ Hassan Suryono, Implementasi dan Sinkronisasi Hak. Asasi Manusia Internasional dan Nasional, dalam Muladi (editor), Op. Cit., hlm. 86.

${ }^{50}$ Masyhur Effendi dan Taufani S. Evandri, Op. Cit., hlm. 57. 
- These rights are the basic minimum requirement for survival of human beings in society;

- These rights can be executed only within the society and are protected and enforced by the authority of the state at all levels.

Usaha melindungi, menghormati, memajukan, dan memenuhi HAM dapat menjadi ukuran tingkat penegakan hukum, peradaban, kemajuan, dan kematangan demokrasi suatu negara. Dengan demikian, menempatkan orang per orang sebagai subyek hukum dan bebas menikmati hak asasinya, menjadi variable utama.

Hakikat penegakan HAM adalah diakui dan dihormatinya human dignity/ martabat kemanusiaan setiap manusia, tanpa membedakan strata sosial, status sosial, status politik, etnik, agama, keyakinan politik, budaya, ras, golongan dan sejenisnya.

Untuk merealisasikan ide dan pemikiran tersebut, masing-masing warga masyarakat hendaknya mengetahui dan lebih penting menyadari posisi dan fungsi yang sedang diemban di dalam sistem kemasyarakatan dan negara. Kuatnya kesadaran akan posisi dan fungsi yang disandang tersebut, maka penghormatan HAM akan dapat berjalan dengan baik, tentu saja tak terlepas juga dengan sistem politik yang dianut.

\section{HAM dan Struktur Sosial Kemasyarakatan}

Institusionalisasi HAM tak dapat dilepaskan dari lingkungan sosial atau habitatnya, yakni masyarakat dimana HAM itu dikembangkan. Terjadi semacam korespondensi antara HAM dan perkembangan masyarakat. HAM memiliki watak sosial dan struktur sosial tersendiri. ${ }^{51}$

Tidak semua bangsa di dunia memiliki kosmologi serta pandangan (outlook) dunia dan kemasyarakatan seperti dunia Barat yang dengan pandangan individualnya tidak dapat disamakan dengan masyarakat Timur (katakanlah Indonesia), yang memiliki pandangan kolektif ${ }^{52}$. Interaksi dan saling memasuki satu sama lain bisa terjadi, tetapi yang satu tidak menggusur yang lain.

51 Satjipto Rahardjo, Op. Cit., hlm. 217.

${ }^{52}$ Memasukkan norma HAM ke dalam UUD Indonesia, merupakan perjuangan panjang. Pertentangan antara para pendiri negara dan perancang konstitusi (kubu M. Yamin dengan kubu Soepomo dan Seokarno) tentang perlu/ tidaknya HAM dimasukkan ke dalam UUD Negara Indonesia. Dalam pandangan Soepomo, HAM sangat identik dengan ideologi liberal-individual, dengan demikian sangat tidak cocok dengan sifat masyarakat Indonesia. Soepomo tidak pernah membayangkan kalau negara yang berasaskan kekeluargaan akan terjadi konflik atau penindasan negara kepada rakyatnya karena negara atau pemerintahan merupakan satu kesatuan, antara 
HAM, tidak dapat dipisahkan dengan pandangan filosofis tentang manusia yang melatarbelakanginya. Di Indonesia, pandangan filosofis ini tertuang dalam nilai-nilai yang disebut Pancasila, dimana hakikat manusia adalah tersusun atas jiwa dan raga, kedudukan kodrat sebagai makhluk Tuhan dan makhluk pribadi, adapun sifat kodratnya sebagai makhluk individu dan makhluk sosial. HAM tidak dapat dipisahkan dengan hakikat kodrat manusia tersebut. Konsekuensinya, HAM senantiasa berkorelasi dengan kewajiban asasi manusia karena sifat kodrat manusia sebagai individu dan makhluk sosial.

HAM yang berangkat dari individualisme masyarakat Barat harus dapat diselaraskan dengan HAM berdasarkan Pancasila yang berbasiskan kolektivisme. Kita harus membuat distingsi, harus dapat membedakan antara individualisme yang disebut-sebut Soekarno sebagai individualisme yang ekstrem (negatif). Individualisme yang ekstrem ${ }^{53}$ memisahkan orang dari masyarakat sama sekali. Individualisme ekstrem inilah yang melahirkan liberalisme, kapitalisme, dan imperalisme. Ada individualisme lain yang positif, yang dapat saja kita terima dan tidak bertentangan dengan Sila II, kemanusiaan yang adil dan beradab. Individualisme yang positif menghargai manusia sebagai makhluk pribadi, yang melepaskan manusia dari kungkungan kolektif, yang memberi kesempatan kepada manusia pribadi untuk dapat berkembang secara wajar, untuk dapat mengembangkan diri menjadi manusia yang utuh, menjadi manusia yang berkepribadian. Atau dengan istilahnya sekarang menjadi manusia yang berkualitas.

Rangkaian sila-sila Pancasila secara terang menginformasikan bahwa kaidah dasar yang merupakan nilai fundamental Pancasila adalah: Ketuhanan, Kemanusiaan, Persatuan, Kerakyatan, dan Keadilan. Nilai dasar ini memberikan arah bagi semua warga negara RI, untuk menyelenggarakan kehidupan yang berbasis sila Pancasila. Dengan kata lain, dalam pelaksanaan HAM dilarang

pemerintah dengan rakyat adalah tubuh yang sama. Pandangan demikian ditolak oleh Yamin. Walhasil, dari pertentangan tersebut dicapai kompromi untuk memasukkan beberapa prinsip HAM ke dalam UUD yang mereka rancang. Wujud dari kompromi tersebut adalah apa yang diatur pada beberapa pasal dalam UUD 1945 (Perdebatan seputar sidang-sidang BPUPKI dalam "Risalah Sidang BPUPKI" terbitan Sekneg tahun 1997, dalam Firdaus, Implikasi Pengaturan HAM dalam UUD terbadap Ius Constituendum, dalam Muladi (editor), Ibid., hlm. 10) hlm. 90 .

53 A. Heuken, SJ., dkk, Ensiklik Politik Pembangunan Pancasila, Yayasan Cipta Loka Caraka, Jakarta, 1988, 
berbuat yang tidak berketuhanan, berkemanusiaan, berpersatuan, berkerakyatan, dan berkeadilan. ${ }^{54}$ Terkait dengan hal ini, Drijarkara ${ }^{55}$ mengemukakan, bahwa :

a. Pancasila memuat hakikat manusianya sendiri, yakni sebuah hakikat manusia yang merujuk pada ada-bersama. Dalam ada-bersama, yang ada bukan lagi "aku dan engkau", melainkan "aku-engkau". Inilah yang menjadi perikemanusiaan itu sendiri, bukan karena status ekonomi atau sosial dari diri manusia tersebut.

b. Sebagai sebuah prinsip, kemanusiaan bersifat universal. Ia perlu diturunkan pada konteks yang spesifik. Sejalan dengan eksistensi manusia yang memanusia dengan menyatu ke dalam alam jasmani, manusia akhirnya membudaya. Kebudayaan ini mengolah alam yang salah satu diantaranya menghasilkan ekonomi. Oleh karenanya, keadilan sosial adalah perikemanusiaan sepanjang ia dilaksanakan dalam bidang ekonomi atau penyelenggaraan perlengkapan dan syarat hidup.

c. Ketuhanan merupakan sumber dari segala sila dalam Pancasila. Dengan demikian, negara Pancasila mengakui bahwa seluruh hidup manusia merupakan gerak ke-Tuhanan, sebagai wujud cinta kasih kepada Tuhan. Dengan demikian, negara Pancasila mengakui ketinggian dan kesucian hidup. Akan tetapi, tidak kemudian negara RI menjadi negara agama. Sebab negara merupakan alat untuk mencapai tujuan kemakmuran bersama sehingga pelaksanaan keagamaan diserahkan kepada religi. Akan tetapi, hal ini tidak menjadi negara Pancasila sebagai negara sekuler, sebab ia mendasarkan praktik kenegaraan kepada sila Ketuhanan.

Dapatlah difahami bahwa nilai-nilai Pancasila adalah seperangkat nilai yang sejajar dengan nilai-nilai HAM global.

Persoalan implementasi nilai-nilai HAM global ke dalam sistem hukum Indonesia yang berlandaskan Pancasila sebagai ideologi ${ }^{56}$ berbangsa dan bernegara sekaligus sumber dari segala sumber hukum, maka untuk melaksanakannya perlu diundangkan dalam peraturan perundang-undangan, baik dalam tataran UU hingga Peraturan Daerah. Sehingga, bila ingin menemukan bagaimana rechtsidee tersebut diwujudkan di dalam hukum HAM di Indonesia, dapatlah ditelusuri jejak Pancasila di dalam hukum positif yang berkaitan dengan HAM.

\footnotetext{
54 Prasetijo Rijadi \& Sri Priyati, Membangun Imu Hukum Mą̧̧ab Pancasila, dalam Satya Arinanto \& Ninuk Triyanti (editor), Memahami Hukum Dari Konstruksi Sampai Implementasi, PT. Raja Grafindo Persada, Jakarta, 2009, hlm. 33.

55 N. Drijarkara, sebagaimana dikutip Syaifullah Arif, Falsafah Kebudayaan, PT. Gramedia Pustaka Utama, Jakarta, 2016, hlm. 49-50.

${ }^{56}$ Ideologi Pancasila dengan Sila II "Kemanusiaan yang adil dan beradab” menuntut supaya manusia diakui dan dihargai menurut martabatnya, baik sebagai pribadi maupun sebagai makhluk sosial. Karena Pancasila sebagai ideologi dan sebagai cita-cita memang sesuai dengan kodrat manusia, maka Pancasila mudah diterima. (Lihat Gunawan Setiardja, Op. Cit., hlm. 32)
} 
Posisi Indonesia dalam hukum juga memerlukan perhatian tersendiri, karena cukup berbeda dengan sosok dan kehadiran negara itu dalam pikiran liberal rule of $l a w^{57}$, dimana masyarakat dan negara berhadap-hadapan dalam posisi konfrontatif.

Di Indonesia, kehadiran negara tidaklah dipertentangkan dengan rakyat. Struktur demikian tercermin dalam ciri kekeluargaan dan kebapakan dari sistem hukumnya. Apabila ciri demikian tidak tercermin dalam perundang-undangan, maka pola pikir liberal rule of law itu akan tetap muncul dalam budaya hukum kita. Dalam konteks legalisme seperti itu, maka negara justru dikehendaki untuk menjadi pelindung dan sekaligus penggerak dinamika masyarakat.

Pengertian HAM sendiri harus difahami bukan secara univoka (bermakna satu), melainkan harus secara analoga. Jadi, ada titik temu sekaligus juga ada titik perbedaan. Secara obyektif, kalau sudah dirumuskan, dituangkan dalam konstitusi, HAM itu berbeda-beda jumlah, isi dan pelaksanaannya, sesuai dengan kultur, watak dan ideologi negara bersangkutan. Seyogyanya tata hukum merupakan eksemplar ratifikasi cita hukum ke dalam berbagai kaidah hukum yang tersusun dalam sebuah sistem. ${ }^{58}$

Pembangunan hukum HAM di Indonesia akan efektif bila ditunjang hukum dan aparat yang memiliki landasan nilai serta norma yang bersumber dari nilainilai dan pandangan hidup bangsa, yaitu Pancasila. ${ }^{59}$ Setidaknya, penyelenggara negara mulai melakukan reformasi cara fikir dengan menempatkan diri bukan hanya sebagai petinggi yang harus dilayani, namun sebagai penyelenggara negara yang berkewajiban memberikan pelayanan tanpa diskriminasi kepada seluruh warga. Reformasi pola fikir ini belum sepenuhnya berjalan. Riak-riak diskriminasi masih sering menghiasi media massa, baik cetak maupun elektronik. Rintihan minoritas pemeluk agama/kepercayaan tertentu masih terdengar. Tuntutan

\footnotetext{
${ }^{57}$ Satjipto Rahardjo, Sisi-sisi Lain dari Hukum di Indonesia, Penerbit Kompas, Jakarta, 2006, hlm.7, mengemukakan bahwa memberikan penafsiran dan mempraktikkan Negara berdasarkan hukum menurut doktrin rule of law, adalah cara berbuat yang kurang merdeka. Sebagai bangsa merdeka, sudah semestinya kita juga ingin berbuat dan berpikir merdeka, termasuk dalam mempraktikkan suatu institusi yang kita rencanakan sebagai Negara berdasar hukum. Rule of law sebagai institusi sosial memiliki struktur sosiologisnya sendiri dan mempunyai akar budaya sendiri pula. Rule of law tumbuh dan berkembang ratusan tahun lamanya seiring dengan pertumbuhan masyarakat bangsa-bangsa Eropa. Itulah sebabnya, rule of law berstruktur sosiologis, atau mempunyai asal-usul sosialnya sendiri. Akar sosial dan akar budaya Eropa.

${ }^{58}$ Ibid.

${ }^{59}$ Kaelan, Pendidikan Pancasila, Paradigma, Yogyakarta, 2001, hlm. 252.
} 
persamaan kesempatan kerja bagi penyandang disabilitas masih menjadi isu besar setiap momen perekrutan PNS. Teriakan orang kesakitan karena menjadi korban penyiksaan oleh aparat penegak hukum masih memenuhi halaman pengaduan lembaga-lembaga monitoring HAM, serta jeritan para ibu yang tanah dan/atau rumahnya digusur dengan alasan pembangunan juga masih menjadi pekerjaan besar bagi bangsa Indonesia.

Situasi di atas layak diapresiasi sebagai progress bangsa Indonesia dalam upaya pemenuhan prinsip HAM. Di masa yang akan datang perkembangan HAM harus didorong untuk tetap berjalan dengan mengedepankan mekanisme demokratis berpijak pada logika kepentingan rakyat yang berbasiskan falsafah Pancasila. Pengembangan HAM, baik dari sisi legislasi maupun perumusan kebijakan harus dilakukan dengan menggunakan mekanisme yang partisipatif. Menurut Suparman Marzuki ${ }^{60}$, mekanisme partisipatif ini dapat dilakukan dengan dua cara, yaitu pertama, mendorong DPR untuk memposisikan dirinya bukan sebagai representasi partai politik dan pembuat UU, namun merupakan kekuatan formal politik rakyat. Partisipasi pada tingkat ini dapat dilakukan dengan melibatkan seluruh komponen masyarakat termasuk elemen organisasi non pemerintah dan gerakan sosial untuk terlibat secara aktif dalam proses legislasi. Kedua, mendorong masyarakat sipil untuk menjadi kekuatan intelektual yang bertugas mengkaji dan merumuskan kebutuhan hukum masyarakat. Perpaduan dua hal di atas diharapkan mampu melahirkan hukum HAM yang memiliki kekuatan perlindungan (protect), penghormatan (respect), dan pemenuhan (fulfill) terhadap hak-hak yang kontekstual dengan kebutuhan substansial masyarakat.

Upaya sinkronisasi dan interpretasi HAM memerlukan legitimasi dan konsensus dari komponen bangsa untuk merumuskan, menjabarkan dan mengintegrasi. Dari sinilah akan dihasilkan harmonisasi nilai HAM nasional dengan HAM universal. ${ }^{61}$

${ }^{60}$ Suparman Marzuki, Politik. Hukum Hak Asasi Manusia Sesudah Reformasi : Refleksi Singkat, Kata Pengantar dalam Eko Riyadi (editor), To Promote : MembacaPerkembangan Hak. Asasi Manusia di Indonesia, Pusat Studi Hak Asasi Manusia Universitas Islam Indonesia (PUSHAM UII), Yogyakarta, 2012, hlm. viii-ix.

${ }^{61}$ Arief Bernard Sidharta, Refleksi Tentang Struktur Ilmu Hukum, Mandar Maju, Bandung, 2000, hlm. 184. 
Menurut Hassan Suryono62, upaya sinkronisasi hukum HAM dunia pada skala nasional haruslah dilakukan secara vertikal dan horizontal. Secara vertikal dilakukan terhadap nilai-nilai HAM universal dengan nilai-nilai HAM lokal. ${ }^{63}$ Terhadap perundang-undangan nasional berdasarkan status yang lebih tinggi dan rendah, sedangkan sinkronisasi horizontal dilakukan terhadap perundangundangan yang sederajat.

Meminjam kerangka pemikiran Gustav Radbruch, sebagai leitstern norma HAM dalam UUD dapat berfungsi regulatif maupun konstitutif. Fungsi regulatif menempatkan norma HAM dalam UUD sebagai batu uji, apakah hukum positif selaras dengan cita-cita HAM yang berdasar Pancasila. Fungsi konstitutif menentukan tanpa semangat HAM dalam UUD, hukum positif akan kehilangan makna sebagai hukum yang bermanfaat bagi kemaslahatan masyarakat.

Sebagai anggota PBB bukan berarti harus melaksanakan semua Deklarasi Universal HAM secara harfiah. Di Indonesia di jumpai keadaan tertentu, situasi tertentu ${ }^{64}$, yang harus diperhatikan dalam melaksanakan HAM dengan tetap berpegang pada ideologi Pancasila.

Dalam kerangka fungsi regulatif inilah agaknya Mahkamah Konstitusi (MK) telah memainkan perannya membatalkan beberapa UU yang dianggap bertentangan dengan norma HAM dalam UUD. MK telah mengajarkan, salah satu cara bagaimana HAM seharusnya dimasyarakatkan, terutama dalam muatan hukum negara. Untuk itu DPR dan Pemerintah dalam rangka ius constituendum

${ }^{62}$ Hassan Suryono, Hak Asasi Manusia dalam Perspektif Politik Hukum, makalah disampaikan dalam Kuliah Perdana Program PPKn FKIP UNS, 16 September 2002, hlm. 4. dalam Muladi (editor), Op. Cit., hlm. 88.

${ }^{63}$ Nilai-nilai HAM lokal dimaksudkan bahwa penghormatan, promosi, perlindungan, dan pemenuhan HAM sangat bergantung pada kearifan lokal masing-masing. budaya, tradisi, dan peradaban tertentu. Kebudayaan merupakan satu-satunya sumber keabsahan hak atau kaidah moral, sehingga HAM mesti dipahami dalam konteks budaya tiap-tiap negara. HAM itu bersifat kontekstual.

${ }^{64}$ Di Indonesia masih dijumpai ragam budaya yang bersemayam dan hidup, melekat dan dipegang teguh oleh masyarakat setempat, meskipun dalam praktiknya pasti ada saja hal yang terkesan tidak sejalan dengan konsep hidup manusia pada umumnya. Beberapa kebiasaan adat di Indonesia yang tidak sejalan dengan konsep kehidupan modern. Sebagai contoh dapat dikemukakan budaya patriarki. Dalam tatanan kehidupan sosial, budaya patriarki selalu menempatkan laki-laki pada level teratas, apapun bentuknya. Akibat posisi yang super ini, sering kali wanita dipandang sebelah mata, tindakan kasar pun juga kerap terjadi, dan faktanya hal ini sudah tak terelakkan, karena budaya kekerasan sudah terpatri sejak zaman dahulu, hingga menjadi kebiasaan yang dianggap wajar terjadi untuk "mendidik" kaum perempuan. Kondisi di atas bila dihubungkan dengan konsep HAM jelas merupakan suatu bentuk pelanggaran sebagaimana dirumuskan dalam ICCPR dan The European Convention of Human Rights dan American Convention on Human Rights yang menentukan bahwa hak untuk bebas dari penyiksaan dan perlakuan yang tidak manusiawi atau merendahkan atau hukuman lainnya merupakan hak yang tidak dapat dikurangi dalam kondisi apapun (non derogable right). 
harus betul-betul cermat membuat konstruksi-konstruksi hukum dalam hukum negara agar selaras dengan cita-cita atau norma HAM yang terkandung dalam UUD 1945. Hal ini merupakan cara lain bagaimana nilai-nilai HAM dibudayakan, terutama dalam hukum Negara.

Perlu satu persepsi, satu pola yang dapat menggerakkan pembaharuan itu, seperti yang dijelaskan oleh Thomas Khun sebagai paradigma ${ }^{65}$ yang memandu arah harmoni pembangunan hukum, karena beragamnya cara pandang dengan sendirinya berimplikasi tersendiri terhadap praktek penegakan hukum HAM.

\section{Penutup}

Implementasi nilai-nilai HAM global ke dalam sistem hukum Indonesia melalui penormaan nilai-nilai HAM ke dalam perundang-undangan RI haruslah merupakan turunan dari nilai-nilai Pancasila sebagai cita hukum bangsa Indonesia. Perumusan dan institusionalisasi HAM tak dapat dilepaskan dari lingkungan sosial, yakni masyarakat dimana HAM itu dikembangkan. Dapat juga dikatakan, bahwa HAM memiliki watak dan struktur sosial tersendiri. Seyogyanyalah pembangunan hukum HAM di Indonesia memperhatikan nilai-nilai serta cita hukum masyarakat Indonesia yakni Pancasila yang merupakan kumpulan nilainilai filsafati bangsa Indonesia. Untuk itu, perlu sinkronisasi dan interpretasi dokumen HAM universal dan nasional terhadap nilai-nilai Pancasila sehingga ditemukan harmonisasi dari keduanya.

\section{Daftar Pustaka}

\section{Buku}

Arinanto, Satya \& Ninuk Triyanti (editor), Memahami Hukum Dari Konstruksi sampai Implementasi, PT. Raja Grafindo Persada, Jakarta, 2009.

Asshiddiqie, Jimly, Perihal Undang-Undang, PT. Raja Grafindo Persada, Jakarta, 2010.

Bolo, Andreas Doweng, dkk., Pancasila Kekuatan Pembebas, Penerbit PT Kanisius, Yogyakarta, 2012.

Budiardjo, Miriam, Dasar-dasar Ilmu Politik, Gramedia, Jakarta, 1997.

65 Thomas Khun, The Structure of Scientific Revolution, Peran Paradigma dalam Revolusi Sains, PT. Remaja Rosdakarya, Bandung, 2002, hlm. 9. 
Darmodiharjo, Darji, dan Sidharta, Penjabaran Nilai-Nilai Pancasila dalam Sistem Hukum Indonesia, PT. Raja Grafindo Persada, Jakarta, 1996.

Donnely, Jack, Universal Human Rights in Theory and Practice, Cornell University Press, Ithaca and London, 2003.

Drijarkara, N. sebagaimana dikutip Syaifullah Arif, Falsafah Kebudayaan, PT. Gramedia Pustaka Utama, Jakarta, 2016.

Erawati, Elly, Bayu Seto Hardjowahono, dan Ida Susanti, BeberapaPemikiran Tentang Pembangunan Sistem Hukum Nasional Indonesia, PT. Citra Aditya Bakti, Bandung, 2011.

Effendi, Masyhur \& Taufani S. Evandri, HAM DAlam Dinamika/ Dimensi Hukum, Politik, Ekonomi, dan Sosial, Ghalia Indonesia, Jakarta, 2014

Goesniadhie, Kusnu, Harmonisasi Hukum, Dalam Perspektif Perundang-undangan (Lex Specialis suatu Masalah), JP BOOKS, Surabaya, 2006.

Hart, H.L.A., Essays on Bentham, Oxford University Press, London, 1982.

Heuken, A. SJ., dkk., Ensiklik Politik Pembangunan Pancasila, Yayasan Cipta Loka Caraka, Jakarta, 1988.

Jacobs, Francis G., The Sovereignty of Law; The European Way, Cambridge Press, Cambridge.

Jauhariah, Dinamika Hukum \& HAM, Penerbit Cintya Press, Jakarta, 2016.

Kaelan, Pendidikan Pancasila, Paradigma, Yogyakarta, 2001.

Kartohadiprodjo, Soediman, Pancasila sebagai Pandangan Hidup Bangsa Indonesia, Gatra Pustaka, Jakarta, 2010.

Khun, Thomas, The Structure of Scientific Revolution, Peran Paradigma dalam Revolusi Sains, PT. Remaja Rosdakarya, Bandung, 2002.

Marzuki, Suparman Politik Hukum Hak Asasi Manusia Sesudah Reformasi : Refleksi Singkat, Kata Pengantar dalam Eko Riyadi (editor), To Promote : MembacaPerkembangan Hak Asasi Manusia di Indonesia, Pusat Studi Hak Asasi Manusia Universitas Islam Indonesia (PUSHAM UII), Yogyakarta, 2012.

Sidharta, Arief Bernard, Refleksi Tentang Struktur Ilmu Hukum, Mandar Maju, Bandung, 2000.

Setiardja, Gunawan, Hak-Hak Asasi Manusia Berdasarkan Ideologi Pancasila, Kanisius, Yogyakarta, 1993.

Purbopranoto, Kuntjoro, Hak-hak Asasi Manusia dan Pancasila, Pradnya Paramita, Jakarta, 1976.

Saidin, OK., Mencari dan Menjadi Hukum Indonesia, Refleksi Pemikiran Prof. Mahadi, PT. Raja Grafindo Persada, Jakarta, 2016. 
Smith, Rhona K., dkk, dalam Knut D. Asplund, Suparman Marzuki, Eko Riyadi (editor), Hukum Hak Asasi Manusia, Pusat Studi Hak Asasi Manusia Universitas Islam Indonesia, Yogyakarta, Cet. Kedua, 2010.

Rahardjo, Satjipto, Ilmu Hukum, PT. Citra Aditya Bakti, Bandung, 2000.

Sosiologi Hukum, Perkembangan Metode dan Pilihan Masalah, Muhamadiyah University Press, Surakarta, 2004.

Sisi-sisi Lain dari Hukum di Indonesia, Penerbit Buku Kompas, Jakarta, 2006.

Shidarta, Hukum Penalaran dan Penalaran Hukum, Buku 1 Akar Filosofis, Genta Publishing, Yogyakarta, 2013.

Weissbordt, David, Hak Asasi Manusia, Tinjauan dari Perspektif Sejarah, dalam Peter Davies, Hak Asasi Manusia; Sebuah Bunga Rampai, Yayasan Obor Indonesia, Jakarta, 1994.

Winarno, Paradigma Baru Pendidikan Kewarganegaraan, PT. Bina Aksara, Jakarta, cetakan Kedua, 2008.

\section{Jurnal}

Trubeck, David M., “Toward a Social Theory of Law; An Essay in the Study of Law and Development", The Yale Law Journal, 1972, Vol. 82.

\section{Majalah}

Huda, Miftakhul, Kamus Hukum Non-Derogable Rights, Majalah Konstitusi No. 43, Agustus 2010.

\section{Internet}

http://pamflet.or.id/blog/hamitukita-6-prinsip-dasar-ham, diakses tanggal 17 Maret 2017. 